\title{
AN INVESTIGATION INTO HETEROGENEITY OF VARIANCE FOR MILK AND FAT YIELDS OF HOLSTEIN COWS IN BRAZILIAN HERD ENVIRONMENTS
}

\author{
Claudio Napolis Costa
}

\begin{abstract}
Heterogeneity of variance in Brazilian herd environments was studied using first-lactation 305-day mature equivalent (ME) milk and fat records of Holstein cows. Herds were divided into two categories, according to low or high herd-year phenotypic standard deviation for ME milk (HYSD). There were 330 sires with daughter records in both HYSD categories. Components of (co)variance, heritability, and genetic correlations for milk and fat yields were estimated using a sire model from bivariate analyses with a restricted maximum likelihood (REML) derivative-free algorithm. Sire and residual variances for milk yield in low HYSD herds were 79 and $57 \%$ of those obtained in high HYSD herd. For fat yield they were 67 and $60 \%$, respectively. Heritabilities for milk and fat yields in low HYSD herds were larger (0.30 and 0.22) than in high HYSD herds (0.23 and 0.20$)$. Genetic correlation between expression in low and high HYSD herds was 0.997 for milk yield and 0.985 for fat yield. Expected correlated response in low HYSD herds based on sires selected on half-sister information from high HYSD was $0.89 \mathrm{~kg} / \mathrm{kg}$ for milk and $0.80 \mathrm{~kg} / \mathrm{kg}$ for fat yield. Genetic evaluations in Brazil need to account for heterogeneity of variances to increase the accuracy of evaluations and the selection efficiency for milk and fat yields of Holstein cows. Selection response will be lower in low variance herds than in high variance herds because of reduced differences in daughter response and among breeding values of sires in low HYSD herds. Genetic investments in sire selection to improve production are more likely to be successful in high HYSD herds than in low HYSD Brazilian herds.
\end{abstract}

\section{INTRODUCTION}

One major component in designing breeding programs is accurate assessment of breeding values. Appropriate modeling of genetic evaluations should take into account potential changes in rank, magnitude of breeding values and genetic gains across environments, which would be an indication of genotype and environment $(\mathrm{Gx} E)$ interaction. In addition to differences in heritabilities and residual variances, genetic correlation between environments is also an important parameter to consider in selection strategies to maximize genetic response in different environments (Van Vleck, 1987).

Interaction between genotype and environment is defined as a change in the relative phenotypic expression of genotypes measured in different environments. Falconer (1952) proposed to utilize genetic correlation to describe $\mathrm{G} \times \mathrm{E}$ interaction by defining the same measure in two environments as distinct characters. Interaction of $\mathrm{G} \times \mathrm{E}$ may involve changes in rank between environments or relative changes in the magnitude of variances between environments.

Most studies of $\mathrm{G} \times \mathrm{E}$ interaction for production traits in dairy cattle were developed in temperate regions and indicated that genetic correlations between environments do not deviate substantially from unity, but that variances and heritabilities differ considerably among envi-

Empresa Brasileira de Pesquisa Agropecuária/Centro Nacional de Pesquisa de Gado de Leite (Embrapa Gado de Leite), Rua Eugênio do Nascimento, 610, Dom Bosco, 36038-330 Juiz de Fora, MG, Brasil. E-mail: cnc8@cnpgl.embrapa.br. ronments (Hill et al., 1983; Logfren et al., 1985; De Veer and Van Vleck, 1987; Carabaño et al., 1989, 1990; Boldman and Freeman, 1990; Dong and Mao, 1990; Short et al., 1990; Stanton et al., 1991). Heterogeneity of variances and heritability estimates have been observed among herd groups differing in mean yield or within-herd standard deviation for milk yield.

An important question if heterogeneous variances are ignored in genetic evaluation is whether the consequent sacrifices in selection accuracy are economically important. The assumption of homogeneous variances has no major effect on sire evaluations if sires are used across herd environments and heritability increases with increasing residual variances (Vinson, 1987; Garrick and Van Vleck, 1987; Winkelman and Schaeffer, 1988; Sullivan and Schaeffer, 1989; Boldman and Freeman, 1990). However, when heritabilities are smallest in the environment in which residual variances are largest, a serious reduction in the efficiency of sire selection can occur by mistakenly assuming variances are homogeneous (Garrick and Van Vleck, 1987). The effect of ignoring heterogeneity of variance is more serious for cow evaluations because they are evaluated within the herd and compared across herds. Thus, more cows would be selected as artificial insemination (AI) bull mothers from more variable herd environments (Everett et al., 1982; Powell et al., 1983). Furthermore, biases accumulate over time if cow evaluations incorporate information from ancestors producing in the same herd, or from animal model cow evaluations which incorporate evaluations of sire and dam (Vinson, 1987; Boldman and Freeman, 1990).

Besides effects on genetic evaluations, heterogeneity of variances among environments may have an eco- 
nomically important effect on selection gains. Powell and Norman (1984) found that the impact of sire selection on increased milk yield was larger in high yield herds than in low yield herds. Greater selection response and consequently a faster rate of genetic improvement were reported for herds with high herd-year phenotypic standard deviation (HYSD) for milk yield in the USA (Meinert et al., 1988; Meinert et al., 1992). Similarly, scaling effects of heterogeneous variances, resulting in a smaller response to USA sire selection for milk in low variance herds than in high variance herds in Latin American countries (Mexico, Colombia and Puerto Rico), were reported by Stanton et al. (1991). Heterogeneous variances among herd environments resulting in reduced selection response suggest unequal genetic progress among environments classified by HYSD. Therefore, ignoring the heterogeneity of variance has consequences for selection choices and the resulting genetic gains, which might reduce the effectiveness of a breeding program (Hill, 1984; Vinson, 1987; Van Vleck, 1987).

The objective of the present study was to quantify differences in sire and residual variances as well as heritability and genetic correlation in genotype expression in different Brazilian herd environments. This information is important for designing evaluation and selection strategies to maximize genetic response in Brazilian herd environments.

\section{MATERIAL AND METHODS}

\section{Data}

Data were provided by the Brazilian Ministry of Agriculture and the Brazilian Agricultural Research Corporation (EMBRAPA). There were 205,217 records from 117,242 Brazilian Holstein cows calving between 1969 and 1994.

Data were edited for errors, redundancy, and incomplete observations, records initiated by abortion, and missing cow identification. Further editing included checks of pedigree and consistency among lactation number, calving age, calving date and calving interval. The final data set for analysis consisted of 110,574 lactation records of cows freshening between 1980 and 1993. Records were adjusted to 305 days in milk and age-parity-season of calving using adjustment factors estimated by Costa (1998) to obtain mature equivalent (ME) milk and fat yields adjusted for parity and season of calving (305d-ME).

\section{Herd-year standard deviation classification}

In order to determine heterogeneity of variance and genetic response across Brazilian herd environments, 305dME records from parities one to five were used to estimate HYSD for milk yield. The HYSD for milk was used to split the data into two classes: low HYSD $(<1120 \mathrm{~kg})$ and high HYSD (> $1150 \mathrm{~kg}$ ). Class break points were chosen to reduce overlap in HYSD classifications. Each herd was confined to a single HYSD class.

After defining HYSD classes, data including only first lactation 305d-ME records were divided into two categories according to HYSD, i.e., low and high HYSD categories. Additional edits in each HYSD category required at least three records per herd-year class, and at least three daughters per sire in two different herds. Three hundred and thirty sires were used in both HYSD categories.

Low and high HYSD categories differed by number of observations, herds, sires, average number of records across herds and sires, averages for milk and fat yields and HYSD for milk (Table I). Except for number of herds, all values were larger in high than in low HYSD herds. Means for milk, fat and HYSD for milk in low HYSD herds were 88,90 and $76 \%$ of those in high HYSD herds.

\section{Pedigree data}

Since most AI bulls used in Brazil were imported from the USA and Canada, information from the exporting country was required to build the numerator relationship matrix (A). The pedigree data file was created using information from the Brazilian Holstein Breeders Association (ABCBRH), United States Department of Agriculture (USDA) and Agriculture Canada. The pedigree data file included the identification code number from the exporting country, and the origin and birth year of each bull, which was classified by the origin of its sire and maternal grandsire (MGS). Seventy-six bulls from Brazil without birth year and parental information were also included in the pedigree file. The pedigree file included 1245 bulls born between 1952 and 1987. Only sire and MGS relationships were considered in the relationship matrix, which comprised 1489 animals.

Table I - Number of records, herds and sires, average number of records across herds and sires, and unadjusted average and standard deviation for milk and fat yields for HYSD ${ }^{1}$ categories.

\begin{tabular}{|lrr|}
\hline & \multicolumn{2}{c|}{ Category } \\
\cline { 2 - 3 } & Low & High \\
\hline Records & 10,072 & 13,789 \\
Herds & 299 & 259 \\
Average number of records & 34 & 53 \\
Sires & 381 & 419 \\
Average number of records & 26 & 33 \\
Milk yield (kg) & & \\
Average & 6432 & 7278 \\
Standard deviation & 1440 & 1584 \\
Fat yield (kg) & & 235 \\
Average & 212 & 51 \\
Standard deviation & 48 & 1319 \\
HYSD (milk, kg) & 1004 & \\
\hline
\end{tabular}

${ }^{1}$ HYSD categories: Low, < $1120 \mathrm{~kg}$; High, > $1150 \mathrm{~kg}$ of milk. 
To account for trends across different origins, genetic groups were defined by birth year and national origin of the bull. The origin of each bull was determined by the nationality of the bull and his sire. The national origin consisted of partial contributions from as many as four populations: Brazil, USA, Canada and other countries grouped together. Twenty groups were thus defined (Table II).

\section{Statistical model}

A multiple trait sire model was used to obtain estimates of variance and covariance components for yield traits between HYSD herd environments. In these analyses milk (and fat) yields in two HYSD classes were considered as different traits. The objective of these analyses was to estimate genetic (co)variances and genetic correlations for milk and fat yields between HYSD herds. These analyses also yield heritabilities for each trait within each HYSD category.

The model equation describing the performance record of each daughter in each HYSD category was:

$$
Z_{n i j k l}=m+h_{n}+c_{i}+g_{j}+s_{j k}+e_{n i j k l}
$$

where $\mathrm{z}_{\text {nijkl }}$ is the performance record of the lth cow of the ith breed grade, daughter of the kth sire of the jth group in the nth herd-year, $m$ is the overall mean, $h_{n}$ is the fixed effect of the nth herd-year, $c_{i}$ is the fixed effect of the ith breed grade, $g_{j}$ is the fixed effect of the jth genetic group,

Table II - Number of bulls per group in the pedigree file.

\begin{tabular}{|c|c|c|c|c|}
\hline Code & $\begin{array}{l}\text { Origin of } \\
\text { bull }^{1}\end{array}$ & $\begin{array}{l}\text { Origin of } \\
\text { sire }^{1} \text { of bull }\end{array}$ & $\begin{array}{c}\text { Bull's } \\
\text { birth year }\end{array}$ & $\begin{array}{r}\text { No. of } \\
\text { bulls }\end{array}$ \\
\hline 1 & $\mathrm{~S}, \mathrm{C}$ & $\mathrm{S}$ & $\leq 1960$ & 93 \\
\hline 2 & & & $1961-1970$ & 102 \\
\hline 3 & & & $1971-1975$ & 208 \\
\hline 4 & & & $1976-1980$ & 180 \\
\hline 5 & & & $\geq 1981$ & 134 \\
\hline 6 & S,C & $\mathrm{C}$ & $\leq 1960$ & 64 \\
\hline 7 & & & $1961-1970$ & 68 \\
\hline 8 & & & $1971-1975$ & 46 \\
\hline 9 & & & $1976-1980$ & 32 \\
\hline 10 & & & $\geq 1981$ & - \\
\hline 11 & B & B & $\leq 1980$ & 13 \\
\hline 12 & & & $\geq 1981$ & 14 \\
\hline 13 & S & & $\leq 1980$ & 23 \\
\hline 14 & & & $\geq 1981$ & 97 \\
\hline 15 & $\mathrm{C}$ & & $\leq 1980$ & 18 \\
\hline 16 & & & $\geq 1981$ & 13 \\
\hline 17 & & M & $\leq 1980$ & 76 \\
\hline 18 & $\mathrm{O}$ & $\mathrm{O}$ & $\leq 1980$ & 36 \\
\hline 19 & & $\mathrm{~S}, \mathrm{C}$ & $\leq 1980$ & 16 \\
\hline 20 & S & M & $\leq 1980$ & 12 \\
\hline Total & & & & 1245 \\
\hline
\end{tabular}

${ }^{1}$ B, Brazil; C, Canada; S, United States; O, other countries, and M, missing origin of sire information. $\mathrm{s}_{\mathrm{jk}}$ is the random effect of the kth sire in the jth group, and $\mathrm{e}_{\mathrm{nijkl}}$ is the random residual associated with the record of the lth cow of grade $i$, daughter of sire $k$ of group $j$ made in herd-year $\mathrm{n}$.

The fixed effect of cow breed grade follows the definition of the Brazilian Holstein Breeders Association, which is based on the origin and ancestry information of the cow (ABCBRH, 1990). In matrix notation this model can be expressed as

$$
\mathbf{y}=\mathbf{X b}+\mathbf{Z Q g}+\mathbf{Z u}+\mathbf{e}
$$

with

$$
\begin{aligned}
\underset{\sim}{\mathbf{y}=} & {\left[\begin{array}{l}
\mathbf{y}_{1} \\
\mathbf{y}_{2}
\end{array}\right]=\left[\begin{array}{cc}
\mathbf{x}_{1} & \mathbf{0} \\
\mathbf{0} & \mathbf{x}_{2}
\end{array}\right]\left[\begin{array}{l}
\mathbf{b}_{1} \\
\mathbf{b}_{2}
\end{array}\right]+\left[\begin{array}{cc}
\mathbf{Z}_{1} \mathbf{Q}_{1} & \mathbf{0} \\
\mathbf{0} & \mathbf{Z}_{2} \mathbf{Q}_{2}
\end{array}\right]\left[\begin{array}{l}
\mathbf{g}_{1} \\
\mathbf{g}_{2}
\end{array}\right]+} \\
& +\left[\begin{array}{cc}
\mathbf{Z}_{1} & \mathbf{0} \\
\mathbf{0} & \mathbf{Z}_{2}
\end{array}\right]\left[\begin{array}{l}
\mathbf{u}_{1} \\
\mathbf{u}_{2}
\end{array}\right]+\left[\begin{array}{l}
\mathbf{e}_{1} \\
\mathbf{e}_{2}
\end{array}\right]
\end{aligned}
$$

where $\mathbf{y}_{\mathbf{t}}$ is the vector of daughter records in HYSD category $\mathrm{t}=1,2$ of order $n_{t} \times 1 ; \mathbf{X}_{t}$ is the known model matrix that associates fixed effects to observations in HYSD category $t$ of order $n_{t} \times a_{t} ; b_{t}$ is the vector of fixed effects in HYSD category t of order $a_{t} \times 1 ; \mathbf{Q}_{t}$ is the known model matrix that associates sires to their respective fixed group effects in HYSD category $t$ of order $\mathrm{q}_{\mathrm{t}} \mathrm{xp}_{\mathrm{t}} ; \mathbf{g}_{\mathrm{t}}$ is the vector of fixed group effects in HYSD category $t$ of order $\mathrm{p}_{t} ; \mathbf{Z}_{\mathrm{t}}$ is the known model matrix that associates random sire effects to observations in HYSD category t of order $n_{t} \times q_{t}$; $\mathbf{u}_{t}$ is the vector of sire random effects in HYSD category $t$ of order $q_{t} \times 1$, and $\mathbf{e}_{t}$ is the vector of residual random effects for each record in HYSD category $t$ of order $n_{t} x 1$. It was assumed that

$$
\mathbf{E}\left[\begin{array}{l}
\mathbf{u} \\
\mathbf{e}
\end{array}\right]=\left[\begin{array}{l}
\mathbf{0} \\
\mathbf{0}
\end{array}\right] \text { and } \mathbf{V}=\operatorname{var}\left[\begin{array}{l}
\mathbf{u} \\
\mathbf{e}
\end{array}\right]=\left[\begin{array}{ll}
\mathbf{D} & \mathbf{0} \\
\mathbf{0} & \mathbf{R}
\end{array}\right]
$$

where,

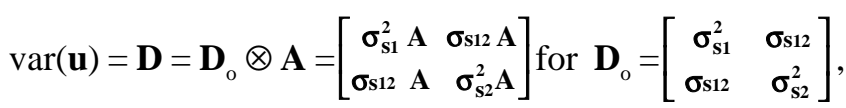

$\mathbf{A}=\left\{{ }_{\mathbf{m}} \mathbf{a}_{\mathbf{k} \mathbf{k}^{\prime}}\right\}$ is the genetic relationship matrix among sires and $\otimes$ is the Kronecker product.

$\operatorname{var}(\mathbf{e})=\mathbf{R}=\left[\begin{array}{cc}\sigma_{\mathbf{e} 1}^{2} \mathbf{I}_{\mathbf{n} 1} & \mathbf{0} \\ \mathbf{0} & \sigma_{\mathbf{e}_{2}}^{2} \mathbf{I}_{\mathbf{n} 2}\end{array}\right]$ for Ini the identity matrix of

order equal to the number of records in HYSD category $\mathrm{i}$ for $\mathrm{i}=1,2$.

These assumptions and the described sire models allow for heterogeneous sire and residual variances, i.e., different sire and residual variance components for each of two HYSD categories, for fat and milk. Also, mates of sires were assumed to be unrelated to each other and to the sires. The sires may have been related to each other through males only. 
Estimation of (co)variance components for milk and fat yields were carried out using multiple trait derivative-free restricted maximum likelihood (MTDFREML) programs developed by Boldman et al. (1995). Convergence of the derivative-free iterative process was attained when the variance of the simplex values ( -2 log-likelihood) was less than $10^{-8}$. In order to guarantee a global maximum, analysis was restarted with previous converged values until the third decimal of -2 log-likelihood did not differ.

Genetic correlations for milk and fat yields between HYSD categories were estimated by:

$$
\hat{r}_{\mathrm{G}}=\hat{\sigma}_{\mathrm{s} 12} /\left(\hat{\sigma}_{\mathrm{s} 1}^{2} \hat{\sigma}_{\mathrm{s} 2}^{2}\right)^{\cdot 5}
$$

and heritability within-HYSD category for each trait by:

$$
\begin{aligned}
& \hat{\mathrm{h}}^{2}{ }_{1}=4 \hat{\sigma}_{\mathrm{s} 1}^{2} /\left(\hat{\sigma}_{\mathrm{s} 1}^{2}+\hat{\sigma}_{e 1}^{2}\right) \text { and } \\
& \hat{\mathrm{h}}^{2}{ }_{2}=4 \hat{\sigma}_{\mathrm{s} 2}^{2} /\left(\hat{\sigma}_{\mathrm{s} 2}^{2}+\hat{\sigma}_{e 2}^{2}\right) .
\end{aligned}
$$

\section{Correlated response}

Expected correlated response for milk and fat yields in low HYSD herds in Brazil from sire selection in high HYSD herds were estimated by the genetic regression $\hat{\sigma}_{\mathrm{s} 12} /$ $\hat{\sigma}_{\mathrm{s} 2}^{2}$, where $\hat{\sigma}_{\mathrm{s} 12}$ is the estimate of sire covariance and $\hat{\sigma}_{\mathrm{s} 2}^{2}$ is the estimate of sire variance for the high HYSD data in each bivariate analysis. Estimates of correlated response indicate the potential for improving production in low HYSD herds (indirect selection) when selection decisions are made using information from high HYSD herds.

\section{RESULTS AND DISCUSSION}

Substantial differences in variance components were observed between low and high HYSD herds (Table III). Smaller sire and residual variances were associated with low HYSD herds, which represented $44 \%$ of all herds. Sire and residual variances for milk yield in the low HYSD herds were respectively 79 and $57 \%$ of the estimates in the high HYSD herds. For fat yield, these figures were 67 and $60 \%$. Magnitude of estimates of sire variance and residual variance components reflected the average HYSD for milk, which confirms that stratifying herds by herdyear variances is an effective criterion for classification of environments for heterogeneous variances (Dong and Mao, 1990; Boldman and Freeman, 1990; Stanton et al., 1991).

Low and high HYSD herds differed by number of sires (Table I). Variance component estimates in high HYSD herds using the 381 sires used in the low HYSD herds were up to $4 \%$ smaller than those reported for high HYSD herds in Table III. Therefore, the contribution of the 38 additional sires to the increase in estimate of variance was practically non-significant. Twenty-six of those sires were from group 17 (Table II), which included Bra-
Table III - Estimates of sire and residual variances, sire covariance (cov), heritability $\left(\mathrm{h}^{2}\right)$, and genetic correlation $\left(\mathrm{r}_{\mathrm{g}}\right)$ for milk and fat yields between HYSD ${ }^{1}$ herds in Brazil.

\begin{tabular}{|lrrrrr|}
\hline Trait & $\begin{array}{c}\text { Sire } \\
\left(\mathrm{kg}^{2}\right)\end{array}$ & $\begin{array}{c}\text { Residual } \\
\left(\mathrm{kg}^{2}\right)\end{array}$ & $\begin{array}{c}\mathrm{Cov} \\
\left(\mathrm{kg}^{2}\right)\end{array}$ & $\mathrm{h}^{2}$ & $\mathrm{r}_{\mathrm{g}}$ \\
\hline Milk & & & & & \\
Low & 73,076 & 898,972 & 81,908 & 0.30 & 0.997 \\
High & 92,220 & $1,579,040$ & & 0.22 & \\
Fat & & 959 & 70 & 0.23 & 0.985 \\
Low & 58 & 1608 & & 0.20 & \\
High & 87 & & & & \\
\hline
\end{tabular}

${ }^{1}$ Low $=$ HYSD $<1120 \mathrm{~kg} ;$ High $=$ HYSD $>1150 \mathrm{~kg}$ of milk.

zilian sires without pedigree information (sire and dam unknown).

Different herd structures and management procedures have been found to be associated with heterogeneity of residual variances in the USA (Weigel et al., 1993). Larger herd size and greater herd average milk yield were associated with larger residual variances for milk yield. Certainly larger herds adopt management practices appropriate for high producing dairy cows, e.g., use of additives and concentrates to supplement forage, grouping of milking cows, veterinary programs, mastitis control and sire selection. Different methods of concentrate feeding, particularly whether they are given in relation to yield or in fixed amounts, and net energy intake affect sire and residual variances (Wiggans and Van Vleck, 1978; Tong et al., 1976).

In Brazil, milk is produced on large, very intensive dairy farms as well as in small family systems. Average number of records per herd used in this study (Table I) shows that herds within the high HYSD class (53 records) are larger than those in the low HYSD class (34 records). In high HYSD herds available resources and management practices may be more similar to those used in temperate regions (appropriate feeding and care) so that higher than average performance is obtained. Low HYSD herds are those with limited resources or less favorable management practices, which restrict the genetic expression of performance traits. Under this scenario, average production as well as sire and residual variances are depressed compared to high HYSD herds.

Heritability estimates for both milk and fat yields were larger in low than in high HYSD herds. Larger heritability estimates in low HYSD herds would suggest that expression of sire genotypes through performance of their progeny is more important in low HYSD than in high HYSD herds. However, sire variances were larger in high HYSD than in low HYSD, which had large heritability due to severe compression of residual variance. These results are in agreement with those reported by Stanton et al. (1991) for Latin American countries, and may have important implications in making decisions about breed- 
ing strategies in (sub)tropical regions. Although heritability estimates may be large, genetic variance is the parameter that dictates potential yield gains by selection. It would be difficult to differentiate breeding values in genetic evaluations in subtropical regions because of reduced genetic variance. Moreover, it would be necessary to apply high selection intensity to attain a significant rate of genetic gain.

Studies in temperate regions have not indicated a discernible trend in heritability by production level, but large estimates are frequently associated with high production levels (Hill et al., 1983; Logfren et al., 1985; De Veer and Van Vleck, 1987; Boldman and Freeman, 1990; Dong and Mao, 1990; Short et al., 1990). Heritability estimates for milk and fat yield obtained in this study are in the range of values reported for those traits in the review of Maijala and Hanna (1974), but are smaller than respective estimates $(0.37$ and 0.36$)$ obtained by Freitas et al. (1982), who also used data from Holstein cows in Brazil.

Genetic correlations between HYSD classes for milk and fat yields were larger than 0.98 , or essentially unity. Analyses quantifying genetic correlation of performance traits between herd groups within country in tropical regions have not been developed. Estimates for milk yield from studies in temperate regions are above 0.85 (Hill et al. 1983; De Veer and Van Vleck, 1987; Dong and Mao, 1990). Similarly the reported genetic correlation estimates for fat yield are larger than 0.93 (Hill et al., 1983; Carabaño et al., 1990).

Large estimates of genetic correlation suggest that significant re-rankings will not occur for breeding values of sires for milk and fat yields between HYSD herds. However, heteroscedasticity of variances for milk and fat yields between HYSD classes certainly affects the magnitude of differences among performance of sires in Brazil. Genetic differences among sires will be more sensitive to environmental conditions in high HYSD herds, which are probably more favorable to phenotypic expression of milking potential.

As long as sires are not equally represented in low and high HYSD herds, sire evaluations will be biased. Sires with progeny only in low HYSD herds would have their breeding values underestimated. Large within-herd variation causes more cows to reach elite status and be selected as bull mothers than in herds with small within-herd variation (Powell et al., 1983; Boldman and Freeman, 1990). Therefore, ignoring heterogeneity of variance in genetic evaluations in Brazil will lead to less accurate evaluations and reduced efficiency of selection.

The genetic (co)variances and residual variances obtained in this study can be used with multiple trait mixed model procedures to provide the best evaluations on which selection can be based. An alternative procedure is to consider adjustments for heterogeneity of variance. As long as these adjustments add little to overall computing requirements, they can be implemented in national genetic evaluations (Wiggans and VanRaden, 1991; Meuwissen et al., 1996).

\section{Correlated response in low HYSD herds to selection in high HYSD herds}

Estimates of genetic correlation for milk and fat yields were relatively large between HYSD categories, suggesting similar rankings for milk and fat yield in both types of HYSD herds. However, differences in milk and fat variances between HYSD herds, which indicate differences among genetic merit of sires, will be larger in high than in low HYSD herds. Heterogeneous variances may result in reduced correlated response in low HYSD herds when selections are based on paternal half-sister information in high HYSD.

Expected correlated responses for milk and fat yields in low HYSD herds, when selection is practiced for the respective trait in high HYSD herds, were calculated using sire (co)variance estimates (Table III). The estimated correlated response coefficients for milk and fat yields in low HYSD herds were respectively 0.89 and 0.80 . Thus, about $89 \%(80 \%)$ of the differences in response for ME milk (ME fat) among daughters of sires in high HYSD herds would be expected in low HYSD herds.

Results from Wiggans and Van Vleck (1978), Meinert et al. (1992), and Weigel et al. (1993) suggested that management factors may be responsible for changes in variance components between herd environments. Selection response is reduced in low HYSD herds because decreased variance compresses differences in breeding values of sires. The reduction in daughter response argues against implementing breeding strategies based on using sires with high breeding values (e.g., imported semen of proven sires) because economic returns are less than predicted from proofs in the originating countries (Holmann et al., 1990). If favorable conditions are associated with larger sire variances in high than in low HYSD herds, economic returns from genetic investments on imported semen to improve production are more likely to be successful in high HYSD herds than in low HYSD Brazilian herd environments.

\section{CONCLUSIONS}

This study clearly revealed differences in variance components between low and high HYSD herd environments in Brazil. Although sire variances were larger in high than in low HYSD herds, severe reduction of residual variances led to larger estimates of heritability for milk and fat yields in low compared to high HYSD herd environments.

Scaling effects of heterogeneous variances lead to smaller differences among sire's breeding values in low than in high HYSD herds. This result suggests that genetic evaluations of cows and sires in Brazil need to ac- 
count for heterogeneity of variance, particularly if daughters of sires are not equally distributed across herds in different HYSD categories.

Genetic correlation estimates for milk and fat yields indicate that sire ranking is not affected by HYSD herd environments where daughters make their records, but differences in daughter response and among breeding values of sires are reduced in low HYSD herd environments suggesting that selection response will be less in low variance herds than in high variance herds. In agreement with previous results from the literature, this study suggests that using imported germ plasm (e.g., semen) to improve production in some herd management situations can be inappropriate because economic returns are reduced for these genetic investments.

Improved husbandry decisions seem to be essential to provide favorable management and feeding practices associated with increased production in Brazilian herd environments. Information about such herd management characteristics would be useful in educating dairy farmers on how to achieve greater levels of herd production or to enhance opportunities of improvement from sire selection.

\section{ACKNOWLEDGMENTS}

The author thanks the reviewers for helpful suggestions and the Associação Brasileira de Criadores de Bovinos da Raça Holandesa for providing the data.

\section{RESUMO}

Registros de produção de leite e de gordura de primeira lactação de vacas da raça Holandesa foram utilizados para estudar a heterogeneidade de variância entre rebanhos, os quais foram classificados em dois grupos (baixo e alto) com base no desvio padrão fenotípico da produção de leite por rebanho-ano (HYSD). Componentes de (co)variância dos efeitos de reprodutor e resíduo, heritabilidade e correlação genética entre grupos de baixo e alto HYSD foram estimados através de análises bivariadas, usandose um modelo reprodutor e o método da máxima verossimilhança restrita com um algoritmo livre de derivações. Os componentes de variância de reprodutor e de resíduo para a produção de leite (produção de gordura) nos rebanhos de baixo HYSD foram respectivamente $79 \%$ e $57 \%$ (67\% e 60\%) dos valores estimados para os rebanhos de alto HYSD. As estimativas de heritabilidade para a produção de leite e de gordura foram maiores $(0,30$ e 0,22$)$ nos rebanhos de baixo HYSD que nos rebanhos de alto HYSD $(0,23$ e 0,20$)$. As correlações genéticas para a produção de leite e de gordura entre os dois grupos de rebanhos foram respectivamente 0,997 e 0,985 . A resposta correlacionada esperada nos rebanhos de baixo HYSD, usando-se informações dos rebanhos de alto HYSD, foram $0.89 \mathrm{~kg} / \mathrm{kg}$ para a produção de leite e 0,80 $\mathrm{kg} / \mathrm{kg}$ para a produção de gordura. As avaliações genéticas no Brasil devem considerar a heterogeneidade de variância para aumentar a precisão das avaliações e a eficiência da seleção para a produção de leite e de gordura na raça Holandesa. A resposta à seleção é menor nos rebanhos de baixo HYSD do que nos rebanhos de alto HYSD devido à redução das diferenças na resposta da progênie e nos valores genéticos dos reprodutores nos rebanhos de baixo HYSD. Os investimentos na seleção de reprodutores para aumento da produção têm maior probabilidade de sucesso nos rebanhos de alto HYSD do que nos rebanhos de baixo HYSD.

\section{REFERENCES}

ABCBRH (Associação Brasileira de Criadores de Bovinos da Raça Holandesa) (1990). Regulamento do Serviço de Registro Genealógico. Gado Holandês, Outubro 1990, pp. 16.

Boldman, K.G. and Freeman, A.E. (1990). Adjustment for heterogeneity of variances by herd level in dairy cow and sire evaluation. J. Dairy Sci. 73: 503-512.

Boldman, K.G., Kriese, L.A., Van Vleck, L.D., Van Tassell, C.P. and Kachman, S.D. (1995). A Manual for the Use of MTDFREML. A Set of Programs to Obtain Estimates of Variance and Covariances (Draft). USDA, Agricultural Research Service, Maryland.

Carabaño, M.J., Van Vleck, L.D., Wiggans, G.R. and Alenda, R. (1989). Estimation of genetic parameters for milk and fat yields of dairy cattle in Spain and the United States. J. Dairy Sci. 72: 3013-3022.

Carabaño, M.J., Wade, K.M. and Van Vleck, L.D. (1990). Genotype by environment interactions for milk and fat production across regions of the United States. J. Dairy Sci. 73: 173-180.

Costa, C.N. (1998). Genetic relationships for milk and fat yields between Brazilian and United States Holstein cattle populations. Ph.D. dissertation, Cornell University, Ithaca, NY.

De Veer, J.C. and Van Vleck, L.D. (1987). Genetic parameters for first lactation milk yields at three levels of production. J. Dairy Sci. 70: 14341441.

Dong, M. and Mao, I.L. (1990). Heterogeneity of (Co)variance and heritability in different levels of intraherd milk production variance and of herd average. J. Dairy Sci. 73: 843-851.

Everett, R.W., Keown, J.F. and Taylor, J.F. (1982). The problem of heterogeneous within herd error variances when identifying elite cows. $J$. Dairy Sci. 65 (Suppl. 1): 100 (Abstract).

Falconer, D.S. (1952). The problem of environment and selection. Am. Nat. 86: 293-298

Freitas, M.A.R., Duarte, F.A.M., Lobo, R.B. and Wilcox, C.J. (1982). Genetic parameters for Holstein milk production in Brazil. Rev. Bras. Genet. V: 147-155.

Garrick, D.J. and Van Vleck, L.D. (1987). Aspects of selection for performance in several environments with heterogeneous variances. J. Anim. Sci. 65: 409-421.

Hill, W.G. (1984). On selection among groups with heterogeneous variance. Anim. Prod. 39: 473-477.

Hill, W.G., Edwards, M.R., Ahmed, M.K.A. and Thompson, R. (1983). Heritability of milk yield and composition at different levels of variability of production. Anim. Prod. 36: 59-68.

Holmann, F., Blake, R.W., Milligan, R.A., Barker, R., Oltenacu, P.A. and Hahn, M.V. (1990). Economic returns from United States artificial insemination sires in Holstein herds in Colombia, Mexico and Venezuela. J. Dairy Sci. 73: 2179-2189.

Logfren, D.L., Vinson, W.E., Pearson, R.E. and Powell, R.L. (1985). Heritability of milk yield at different herd means and variance for production. J. Dairy Sci. 68: 2737-2739.

Maijala, K. and Hanna, M. (1974). Reliable phenotypic and genetic parameters in dairy cattle. Proceedings of the 1st World Congress on Genetics Applied Livestock Production, Madrid, Spain, I: 541-563.

Meinert, T.R., Pearson, R.E., Vinson, W.E. and Cassell, B.G. (1988). Effect of within-herd variance and herd mean production on response to selection within herd. J. Dairy Sci. 71: 3405-3414.

Meinert, T.R., Pearson, R.E., Vinson, W.E. and Hoyt, R.S. (1992). Estimates of genetic trend in an artificial insemination progeny test program and their association with herd characteristics. J. Dairy Sci. 75: 2254-2264.

Meuwissen, T.H.E., De Jong, G. and Engel, B. (1996). Joint estimation of breeding values and heterogeneous variances of large data files. J. Dairy Sci. 79: 310-316.

Powell, R.L. and Norman, H.D. (1984). Response within herd to sire selection. J. Dairy Sci. 67: 2021-2027. 
Powell, R.L., Norman, H.D. and Weinland, B.T. (1983). Cow evaluation at different milk yield of herds. J. Dairy Sci. 66: 148-154.

Short, T.H., Blake, R.W., Quaas, R.L. and Van Vleck, L.D. (1990). Heterogenous within-herd variance. 1. Genetic parameters for first and second lactation milk yields of grade Holstein cows. J. Dairy Sci. 73: 3312-3320.

Stanton, T.L., Blake, R.W., Quaas, R.L., Van Vleck, L.D. and Carabaño, M.J. (1991). Genotype by environment interaction for Holstein milk yield in Colombia, Mexico and Puerto Rico. J. Dairy Sci. 74: 17001714.

Sullivan, P.G. and Schaeffer, L.R. (1989). Regional heterogeneity of variances and its effect on Canadian Holstein sire evaluation. Can. J. Anim. Sci. 69: 605-612.

Tong, A.K.W., Kennedy, B.W. and Moxley, J.E. (1976). Effects of correcting for feeding levels on estimates of genetic parameters of milk yield and composition. Can. J. Anim. Sci. 56: 523-529.
Van Vleck, L.D. (1987). Selection when traits have different genetic and phenotypic variances in different environments. J. Dairy Sci. 70: 337-344.

Vinson, W.E. (1987). Potential biases in genetic evaluations from differences in variation within herds. J. Dairy Sci. 70: 2450-2455.

Weigel, K.A., Gianola, D., Yandell, B.S. and Keown, J.F. (1993). Identification of factors causing heterogeneous within-herd variance components using a structural model for variances. J. Dairy Sci. 76: 1466-1478.

Wiggans, G.R. and Van Vleck, L.D. (1978). Evaluation of sires in herds feeding differing proportions of concentrates and roughages. J. Dairy Sci. 61: 246-249.

Wiggans, G.R. and VanRaden, P.M. (1991). Method and effect of adjustment for heterogeneous variance. J. Dairy Sci. 74: 4350-4357.

Winkelman, A. and Schaeffer, L.R. (1988). Effect of heterogeneity of variance on dairy sire evaluation. J. Dairy Sci. 71: 3033-3039.

(Received April 9, 1998) 
